Jurnal Widya Laksana, Vol.11, No.1, Januari 2022

\title{
PENINGKATAN KETERAMPILAN GURU DALAM MENGOPERASIKAN ZOOM MEETING DAN MENGELOLA GOOGLE FORM UNTUK MENDUKUNG PROSES DAN EVALUASI BELAJAR DARI RUMAH (BDR)
}

\author{
Sukirman ${ }^{1}$, Sarwahdi ${ }^{2}$, Arie Setyaga Handika ${ }^{3}$ \\ ${ }^{1,2,3}$ Pendidikan Teknik Informatika, Universitas Muhammadiyah Surakarta \\ e-mail: sukirman@ums.ac.id, a710160036@student.ums.ac.id, \\ a710160104@student.ums.ac.id
}

\begin{abstract}
Abstrak
Aktivitas belajar dari rumah (BDR) merupakan kegiatan belajar mengajar beserta evaluasinya yang dilakukan dari rumah secara daring. Untuk mendukung aktivitas tersebut dibutuhkan aplikasi pendukung, antara lain Zoom Meeting sebagi media komunikasi berbasis video secara real-time dan Google Form sebagai perangkat evaluasi. Kegiatan pengabdian masyarakat ini bertujuan untuk meningkatkan keterampilan guru SD Muhammadiyah 16 Karangasem, Laweyan, Surakarta, dalam mengoperasikan aplikasi Zoom Meeting dan mengelola Google Form guna mendukung proses dan evaluasi BDR. Metode yang digunakan terbagi menjadi 4 tahap yaitu analisis, formulasi permasalahan, tindakan solutif, dan evaluasi. Tindakan solutif dibuat dalam bentuk pelatihan yang terdiri dari ceramah singkat, tutorial, dan praktik mandiri. Evaluasi dilakukan setelah selesai kegiatan menggunakan kuesioner online. Hasil evaluasi dari 24 guru partisipan yang terlibat menunjukkan bahwa nilai rata-rata setiap item pertanyaan kuesioner adalah sama dengan atau di atas $80 \%$. Hasil kuesioner juga menunjukkan bahwa peserta merasa memperoleh informasi sesuai dengan yang diharapkan untuk mendukung aktivitas BDR dan mereka merasa puas dengan kegiatan yang dilaksanakan. Dengan demikian dapat dikatakan bahwa kegiatan ini berjalan sesuai dengan sasaran dan tujuan yang dibuat di tahap analisis awal.
\end{abstract}

Kata kunci: Belajar dari rumah, bdr, zoom meeting, google form, evaluasi.

\begin{abstract}
Activities of learning from home (BDR) are teaching and learning accompanied by the evaluations conducted from home by online. To support the activities, supporting applications were needed, namely Zoom Meeting for real-time communication based on video and Google Form for evaluation tool. This community service activity aims to improve the skills of teachers at SD Muhammadiyah 16 Karangasem, Laweyan, Surakarta, in operating the Zoom Meeting application and managing Google Forms to support the BDR process and evaluation. The method used was divided into 4 stages, namely analysis,
\end{abstract}


problem formulation, solutive actions, and evaluation. The solutive actions made in the form of training consisting of short lectures, tutorials, and independently practice. Evaluation was carried out after completed the activity using an online questionnaire for 24 techears as involved participants. The evaluation results show that the mean score of each item asked to the participants through the questionnaire is equal to or above $80 \%$. The questionnaire also showed that participants felt that they obtained the information as desired for BDR activities and were satisfied with the activities. Thus it can be stated that this community service activity was running well and appropriate to the goals and objectives made in the analysis stage.

Keywords: Learn form home, bdr, zoom meeting, google form, evaluation

\section{PENDAHULUAN}

Belajar dari rumah (BDR) merupakan aktivitas belajar dan mengajar antara siswa dan gurunya yang dilakukan dari rumah masingmasing secara online. Kegiatan BDR menjadi bersifat wajib karena dunia sedang mengalami wabah Coronavirus Diseases 2019 (Covid-19), termasuk di Indonesia (Sari et al., 2020). Sehingga hampir semua guru mengalami perubahan realita model pembelajaran, termasuk guru junior dan senior (Dvir \& Schatz-Oppenheimer, 2020). Salah satu tujuan BDR yaitu untuk mencegah penyebaran Covid-19. Pemerintah melalui Menteri Pendidikan dan Kebudayaan mengeluarkan Surat Edaran (SE) No. 4 tahun 2020 tentang pelaksanaan kebijakan pendidikan dalam masa darurat penyebaran Covid19 yang mengharuskan kegiatan BDR dilakukan oleh guru dan peserta didik. Bukan hanya di tingkat Universitas, implementasi BDR juga diterapkan sampai ke tingkat sekolah Dasar maupun PAUD (Dewi, 2020). Akibatnya, semua aktivitas pembelajaran harus dilakukan secara online, mulai dari penyampaian materi hingga evaluasi hasil belajar yang biasanya dilakukan secara offline.

Untuk mendukung kegiatan BDR, diperlukan perangkat atau aplikasi yang dapat digunakan agar dapat berkomunikasi antara guru dan siswa secara langsung dalam waktu nyata (real-time). Beberapa aplikasi itu antara lain Zoom Meeting, Google Meet, Webex Meet, dan Skype. Salah satu yang populer dan banyak digunakan adalah Zoom Meeting, sebuah aplikasi yang memungkinkan pengguna untuk melakukan tatap muka secara online berbasis cloud internet (Mujahidin et al., 2020). Aplikasi ini menyediakan layanan konferensi jarak jauh, serta kombinasi antara video conference, online meeting, chatting, dan screen sharing secara real-time. Partisipan yang bisa bergabung dalam pertemuan online melalui aplikasi Zoom juga ini bisa mencapai 100 orang untuk aplikasi versi gratis. Sementara, versi berbayarnya dapat menampung hingga ribuan peserta. Selain itu, aplikasi ini juga mudah digunakan bagi partisipan, sebab mereka bisa langsung bergabung dengan hanya menekan link yang disediakan. Mereka juga memiliki pilihan tentang jenis perangkat yang 
akan digunakan, sebab aplikasi ini dapat dijalankan pada berbagai platform mulai dari komputer desktop, komputer tablet serta smartphone yang semakin memudahkan untuk bergabung. Dengan demikian, aplikasi Zoom Meeting ini merupakan salah satu aplikasi yang sesuai untuk digunakan pada aktivitas BDR termasuk lingkungan sekolah dasar (SD).

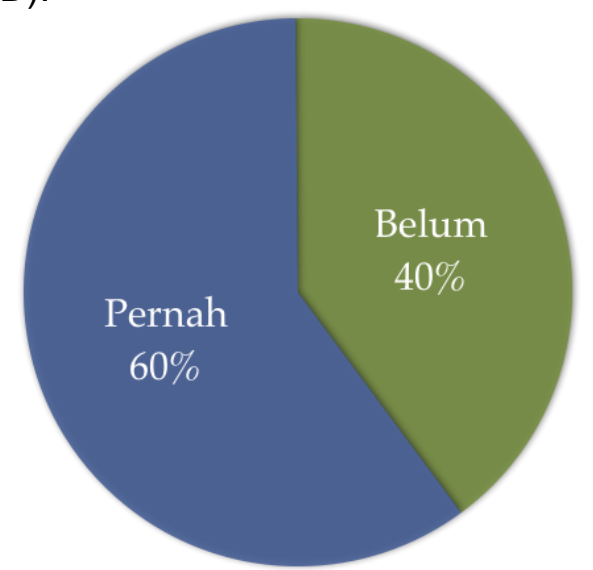

Gambar 1. Hasil survei penggunaan Zoom Meeting

Dalam menyelenggarakan
pertemuan online menggunakan aplikasi Zoom Meeting untuk aktivitas $\mathrm{BDR}$, terdapat satu peran yang harus diketahui oleh guru, yaitu peran sebagai host atau bisa dikatakan sebagai tuan rumah. Tugas utama seorang host dalam aplikasi Zoom Meeting yaitu mengatur pertemuan dan memoderasi partisipan saat pertemuan berlangsung (Haqien \& Rahman, 2020). Seorang host dapat mengundang dan membagikan link atau tautan pertemuan ke calon peserta agar dapat bergabung dengan pertemuan yang diselenggarakan. Seorang host juga bisa mengatur audio speaker peserta apakah diijinkan untuk bersuara atau tidak agar gangguan dalam pertemuan online tidak terjadi. Dengan demikian, keterampilan menjadi host seperti ini sangat penting untuk mendukung aktivitas BDR. Akan tetapi, belum semua guru memiliki kemampuan dan keberanian untuk menjadi seorang host, misalnya di SD Muhammadiyah 16 Karangasem, Laweyan, Surakarta.

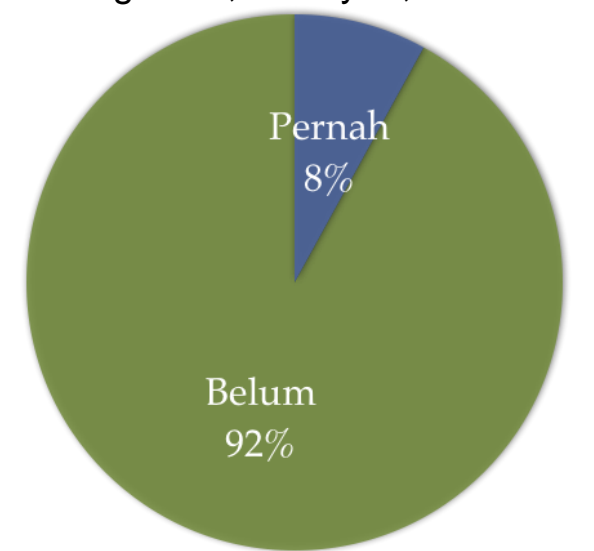

Gambar 2. Hasil survei terkait pengalaman menjadi host

Di tahap analisis awal sebelum pelaksanaan tindakan solutif, kami mengidentifikasi kebutuhan guru peserta menggunakan kuesioner secara online melalui Google Form. Hasil kuesioner dari 25 guru calon peserta menunjukkan bahwa hanya 2 orang atau $8,3 \%$ yang menyatakan pernah menjadi host menggunakan aplikasi Zoom Meeting seperti ditampilkan pada Gambar 2. Padahal, mayoritas (60\%) guru, seperti ditunjukkan pada Gambar 1, sudah mengetahui dan pernah menggunakan aplikasi tersebut, tetapi belum sampai pada level menjadi seorang host. Untuk itulah, perlu diadakan suatu kegiatan untuk meningkatkan keterampilan guru dalam mengoperasikan Zoom Meeting sebagai host guna mendukung aktivitas 
BDR. Sebab seorang guru memiliki peran yang sangat vital saat aktivitas BDR berlangsung, mulai dari mengatur waktu tatap muka online, menyampaikan materi, hingga memoderasi siswa sebagai partisipan dalam pertemuan. Peran tersebut bisa dikatakan menjadi satu tanggung jawab setiap personal guru terhadap siswa yang diajarnya.

Kegiatan pelatihan tentang pemanfaatan aplikasi video conference Zoom dan Google Meet pernah dilakukan oleh Rohman \& Rochmawati (2020), akan tetapi metode yang digunakan masih sebatas penyampaian materi tanpa praktik menjadi host secara langsung. Selain itu, peran guru untuk mengevaluasi kegiatan BDR juga belum disampaikan, sehingga masih terbatas pada proses kegiatan BDR.

Selain sebagai fasilitator dalam proses pembelajaran, kegiatan lain yang menjadi tanggung jawab guru yaitu melakukan evaluasi hasil belajar (Magdalena, Hayati, et al., 2020). Normalnya, evaluasi pembelajaran dilakukan dalam bentuk ujian yang disampaikan secara langsung di dalam kelas. Namun karena aktivitas ini dilakukan secara online, maka evaluasinya pun harus dilakukan secara online. Salah satu perangkat lunak yang dapat digunakan untuk evaluasi sistem pembelajaran online yaitu Google Form (Mulyadi, 2020). Google form merupakan aplikasi formulir berbasis cloud jaringan internet yang memungkinkan pengguna untuk membuat model evaluasi secara online dan membagikannya ke audiens. Selain itu, Google form juga dapat digunakan untuk membuat kuesioner (Sukirman et al., 2019), sehingga menjadikan perangkat ini memiliki keunggulan yang lebih dibanding aplikasi lain. Dengan memiliki keahlian dan keterampilan mengolah formulir dengan Google Form ini, seseorang dengan mudah dapat membuat evaluasi proses pembelajaran maupun membuat kuesioner secara online.

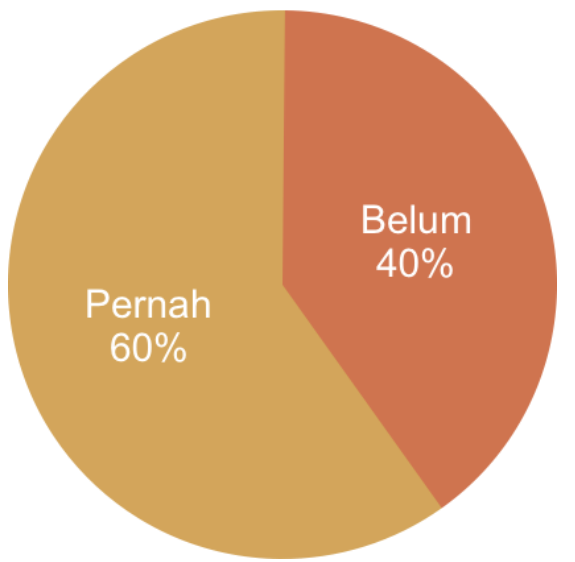

Gambar 3. Hasil survei terkait pengalaman penggunaan Google Form

Berdasarkan analisis awal melalui survei secara online terhadap 25 guru di SD Muhammadiyah 16 Karangasem, Laweyan, Surakarta, diperoleh informasi bahwa sebagian besar guru yang mengajar memang pernah menggunakan Google Form, ilustrasinya seperti ditunjukkan pada Gambar 3, sebanyak 60\% guru pernah menggunakan Google Form. Tujuan penggunaan pun bermacam-macam, seperti ditunjukkan pada Tabel 1, antara lain untuk ulangan, evaluasi, tugas, menyampaikan materi, dan soal online. Sebagian besar guru menggunakan Google Form sebagai media untuk ulangan dan tugas. Namun demikian, ketika diberi pertanyaan tentang apa yang ingin diketahui dari kegiatan pelatihan dalam 
Jurnal Widya Laksana, Vol.11, No.1, Januari 2022

hal pemanfaatan Google Form, para guru menyatakan bahwa mereka memiliki berbagai keinginan dan tujuan antara lain ingin mengetahui proses pembuatan form secara mudah serta tips dan triknya, ingin mengetahui cara mengaplikasikannya dalam BDR, ingin mengetahui penggunaan aplikasi Zoom dan Google Form secara bersamaan, serta beberapa tujuan lain yang dapat meningkatkan kualitas kegiatan BDR.

Tabel 1. Tujuan penggunaan Google Form oleh guru

\begin{tabular}{clc}
\hline No. & \multicolumn{1}{c}{ Tujuan } & Persentase \\
\hline 1. & Ulangan & $31 \%$ \\
2. & Evaluasi & $8 \%$ \\
3. & Tugas & $23 \%$ \\
4. & Menyampaikan materi & $15 \%$ \\
5. & Soal online & $15 \%$ \\
6. & Belum pernah & $8 \%$ \\
\hline
\end{tabular}

dalam jumlah besar tersebut mengakibatkan kurang efektif.

Dari permasalahan yang diuraikan di atas, kegiatan ini bertujuan untuk meningkatkan kualitas BDR secara daring di SD Muhammadiyah 16 Karangasem, Laweyan, Surakarta. Kegiatan ini memberikan kontribusi terhadap guru terkait keterampilan menggunakan aplikasi Zoom guna mendukung aktivitas BDR serta keahlian guru dalam mengelola Google Form sebagai perangkat evaluasi. Dengan demikian, BDR dapat dijalankan secara berkualitas meskipun tanpa bertatap muka langsung seperti kegiatan belajar mengajar secara normal. Bukan hanya menekankan pada aktivitas belajar tetapi juga evaluasi belajar sehingga keduanya dapat berjalan beriingan.

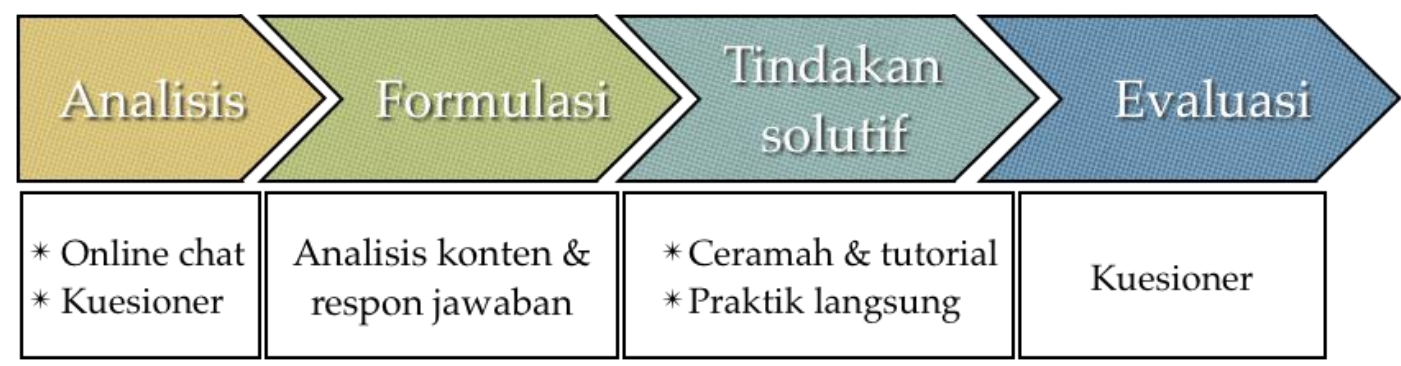

Gambar 4. Desain pelaksanaan kegiatan

Kegiatan pelatihan tentang penggunaan Google Form pernah juga dilaksanakan oleh Ritonga et al.,(2020), akan tetapi metode penyampaiannya masih berupa demonstrasi oleh nara sumber dan peserta hanya sebatas melihat. Sehingga menjadikan peserta pasif dan kurang interaktif. Apalagi, suasana pelatihan yang dirancang

\section{METODE}

Secara umum, metode yang diterapkan dalam kegiatan ini dapat dirancang seperti pada pada Gambar 5. Secara umum dapat dibagi menjadi 4 tahap, yaitu analisis, formulasi permasalahan, tindakan solutif, dan evaluasi hasil kegiatan. Secara lebih detil, penjelasan tiap tahap dan alat 
ukur yang digunakan dapat diuraikan sebagai berikut.

\section{Analisis Kondisi}

Tahap awal sebelum melaksanakan kegiatan ini adalah analisis, yaitu penyelidikan terhadap subjek untuk mengetahui secara lebih detil tentang kondisi, keadaan dan permasalahan yang dihadapi. Analisis kondisi dilakukan menggunakan obrolan singkat atau online chat dengan salah satu guru sebagai koordinator melalui pemanfaatan teknologi chatting WhatsApp. Sesekali juga dilakukan diskusi melalui sambungan telpon seluler apabila terdapat hal-hal yang kurang jelas dan perlu dikonfirmasi secara langsung. Tujuannya yaitu untuk koordinasi lebih jauh supaya kegiatan dapat berjalan dengan baik dan lancar.

Tabel 2. Kuesioner untuk menganalisis kondisi dan permasalahan

\begin{tabular}{cl}
\hline No & \multicolumn{1}{c}{ Pertanyaan } \\
\hline 1. & $\begin{array}{l}\text { Apakah mengetahui aplikasi Zoom } \\
\text { Meeting? }\end{array}$ \\
2. & $\begin{array}{l}\text { Apakah pernah menggunakan aplikasi } \\
\text { Zoom Meting? }\end{array}$ \\
3. Apakah pernah menjadi host saat \\
menggunakan aplikasi Zoom Meeting \\
conference?
\end{tabular}

Analisis yang kedua dilakukan menggunakan kuesioner online melalui Google Form yang di dalamnya berisi beberapa pertanyaan singkat untuk memetakan kondisi dan permasalahan yang dihadapi. Kuesioner dibagikan kepada guru koordinator melalui perangkat pesan singkat WhatsApp dan diteruskan ke guru lain yang akan menjadi partisipan dalam kegiatan. Beberapa pertanyaan yang terdapat dalam kuesioner tersebut disajikan dalam Tabel 2. Selain pertanyaan tersebut, dalam kuesioner juga ditanyakan nama lengkap, jenis kelamin, dan umur yang diklasifikasikan ke dalam 6 kelompok, yaitu kurang dari 24 tahun, 24-29 tahun, 30-33 tahun, 3439 tahun, 40-44 tahun, dan lebih dari 45 tahun. Tujuannya yaitu agar memperoleh gambaran tentang calon partisipan yang akan terlibat apakah termasuk kalangan generasi muda atau generasi tua. Sebab lebih mudah dan cepat saat menyampaikan materi di depan generasi mudah dibanding dengan generasi yang lebih tua.

\section{Formulasi Permasalahan}

Dari kuesioner yang dibagikan di tahap analisis, diperoleh jawaban yang dapat digunakan untuk merumuskan permasalahan. Tujuan formulasi yaitu untuk menyusun atau merumuskan masalah menjadi sebuah bentuk yang tepat sehingga memudahkan dalam mencari solusi dan menyelesaikannya. Selain itu, formulasi ini perlu dilakukan agar strategi pemecahan masalah yang akan digunakan tersebut tepat sasaran sesuai dengan kondisi yang terjadi di lapangan. Strategi yang digunakan dalam formulasi ini yaitu menggunakan analisis konten terhadap jawaban yang 
Jurnal Widya Laksana, Vol.11, No.1, Januari 2022

diberikan oleh responden berdasarkan kuesioner yang sudah didistribusikan di awal sebelum pelaksanaan kegiatan. Respon jawaban dari responden dapat memberikan gambaran seperti apa permasalahan yang dihadapi dalam hal pelaksanaan BDR. Dengan demikian, solusi yang diberikan tersebut sesuai dengan kebutuhan untuk menjalankan aktivitas BDR secara lebih baik.

\section{Tindakan Solutif}

Formulasi

permasalahan

digunakan sebagai dasar dalam menentukan tindakan solutif yang akan dilakukan untuk menyelesaikan permasalahan. Sebelumnya, permasalahan telah diformulasikan bahwa keterampilan guru dalam mengoperasikan Zoom Meeting untuk aktivitas BDR dan pengelolaan Google Form untuk evaluasi pembelajaran masih belum maksimal. Tindakan solutif yang ditawarkan yaitu melaksanakan kegiatan pelatihan dalam bentuk ceramah dan tutorial serta bimbingan praktik secara langsung. Penyampaian ceramah, tutorial dan praktik langsung dibagi menjadi dua sesi karena terdapat dua materi utama, yaitu Zoom Meeting dan Google Form. Kedua sesi tersebut dilakukan dengan metode yang hampir sama, yaitu didahului dengan ceramah singkat dan dilanjutkan dengan tutorial dan praktik mandiri secara langsung.

Materi ceramah yang

disampaikan di bagian awal untuk memahami secara umum tentang fungsi dan jenis aplikasi yang biasanya digunakan untuk BDR, dilanjutkan dengan uraian tentang keunggulan dan kekurangan dari aplikasi tersebut. Beberapa contoh aplikasi sejenis juga disampaikan untuk memberikan gambaran dan wawasan bahwa sebenarnya bukan hanya aplikasi Zoom Meeting dan Google Form saja yang dapat digunakan sebagai perangkat pendukung BDR beserta evaluasinya, tetapi masih ada alternatif lain yang tidak kalah bagusnya. Sehingga, pengetahuan peserta menjadi bertambah dan wawasan mereka menjadi lebih terbuka. Selain itu, juga disampaikan pula syarat-syarat yang harus dipenuhi ketika ingin menggunakan aplikasi berbasis cloud tersebut, salah satunya yaitu harus memiliki akun email, misalnya Google mail sebagai syarat yang diperlukan ketika akan menggunakan aplikasi Google Form.

Persyaratan harus memiliki email ini harus dipenuhi oleh semua guru calon peserta supaya dapat melakukan praktik secara langsung mengoperasikan aplikasi Zoom Meeting dan mengelola Google Form pada saat tutorial disampaikan. Persyaratan ini disampaikan di awal agar calon peserta memiliki persiapan terutama terkait dengan nama akun email serta kata sandinya sehingga waktunya dapat difokuskan pada praktik mengoperasikan Zoom Meeting dan mengelola Google Form. Selain harus memiliki akun email, dalam praktik langsung juga memerlukan perangkat untuk menjalankan aplikasi, yaitu berupa komputer personal atau laptop maupun smartphone. Dengan demikian, para peserta bisa langsung praktik menjadi host sekaligus partisipan dalam suatu pertemuan online yang dibuatnya. 


\section{Evaluasi}

Evaluasi merupakan salah satu tahap penting yang digunakan sebagai identifikasi untuk mengukur atau menilai tingkat tercapainya suatu program atau kegiatan apakah sudah sesuai rencana dan tujuan yang ingin dicapai (Magdalena, Susanti, et al., 2020). Dalam hal ini, evaluasi digunakan untuk mengetahui sejauh mana respon atau tanggapan peserta terhadap kegiatan yang telah dilaksanakan. Selain itu, evaluasi juga digunakan untuk mengukur sejauh mana pemahaman peserta setelah mengikuti kegiatan. Hasil evaluasi digunakan sebagai dasar untuk mengambil keputusan sekaligus bahan pertimbangan untuk melakukan perbaikan atas kekurangan yang ditemui selama kegiatan berlangsung.

Instrumen yang digunakan untuk evaluasi adalah kuesioner yang berisi kombinasi antara pertanyaan tertutup dan terbuka. Pertanyaan tertutup berisi jawaban pilihan berupa yang nilainya menggunakan skala Likert bertingkat antara 1-5, dimana nilai 1 memiliki arti sangat tidak setuju dan nilai 5 artinya sangat setuju. Total jawaban diakumulasi dalam bentuk persentase diinterpretasikan menjadi 5 kategori, yaitu sangat kurang (0-20\%), kurang (21\%-40\%), cukup (41\%-60\%), baik (61\%-80\%), dan sangat baik (81\%$100 \%$ ) (Riduwan, 2007). Sementara, pertanyaan terbuka memberikan keleluasaan peserta untuk mengisi jawaban sesuai dengan yang dipikirkan tiap peserta, sehingga jawaban antar peserta tidak sama. Adapun pertanyaan yang terdapat dalam instrumen evaluasi ini seperti terlihat pada Tabel 3, dimana pertanyaan nomor 1-6 merupakan pertanyaan tertutup sementara nomor 7-8 merupakan pertanyaan terbuka. Pertanyaan tertutup untuk mengetahui seberapa jauh tingkatan persepsi peserta, sedangkan pertanyaan terbuka untuk memperoleh jawaban variatif dari setiap peserta.

Tabel 3. Pertanyaan dalam instrumen evaluasi

\begin{tabular}{|c|c|c|}
\hline No & Kode & Pertanyaan \\
\hline 1. & P1 & $\begin{array}{l}\text { Setelah mengikuti kegiatan ini } \\
\text { saya menjadi lebih tahu cara } \\
\text { mengoperasikan Zoom Meeting } \\
\text { sebagai host untuk pembelajaran } \\
\text { daring. }\end{array}$ \\
\hline 2. & $\mathrm{P} 2$ & $\begin{array}{l}\text { Saya mendapatkan informasi yang } \\
\text { diinginkan dari kegiatan pelatihan } \\
\text { ini untuk mendukung kegiatan } \\
\text { BDR. }\end{array}$ \\
\hline 3. & P3 & $\begin{array}{l}\text { Setelah mengikuti kegiatan } \\
\text { pelatihan ini saya menjadi lebih } \\
\text { tahu kegunaan dan manfaat dari } \\
\text { Google Form untuk pembelajaran } \\
\text { daring }\end{array}$ \\
\hline 4. & P4 & $\begin{array}{l}\text { Saya akan menggunakan Google } \\
\text { Form ini sebagai salah satu } \\
\text { strategi untuk evaluasi dalam } \\
\text { pembelajaran daring. }\end{array}$ \\
\hline 5. & P5 & $\begin{array}{l}\text { Secara umum, saya merasa puas } \\
\text { dengan kegiatan dan materi yang } \\
\text { disampaikan. }\end{array}$ \\
\hline 6. & P6 & $\begin{array}{l}\text { Materi yang disampaikan sudah } \\
\text { sesuai dengan yang saya } \\
\text { harapkan. }\end{array}$ \\
\hline 7. & P7 & $\begin{array}{l}\text { Sebutkan pelatihan lain yang Anda } \\
\text { inginkan guna mendukung } \\
\text { pembelajaran daring. }\end{array}$ \\
\hline 8. & P8 & $\begin{array}{l}\text { Mohon berikan saran, kritik, dan } \\
\text { atau masukan atas kegiatan hari } \\
\text { ini. }\end{array}$ \\
\hline
\end{tabular}

\section{Partisipan}

Partisipan yang terlibat dalam kegiatan ini adalah guru SD Muhammadiyah 16 Karangasem, 
Laweyan, Surakarta sebanyak 24 orang dari berbagai latar belakang ilmu atau mata pelajaran yang diampu mulai dari guru agama, seni, hingga guru wali kelas. Sebanyak 70,8\% (17 orang) guru berjenis kelamin perempuan, dan $29,2 \%$ (7 orang) adalah laki-laki. Sebagian besar berusia di atas 45 tahun, yaitu sebanyak 29,2\% (7 orang), disusul berusia 34-39 tahun dan 24-29 tahun yang masing-masing 25\% (6 orang). Sisanya berumur 40-44 tahun sebanyak $12,5 \%$ (3 orang) dan 30-33 tahun sebesar 8,3\% (2 orang). Dari data tersebut dapat diketahui bahwa sebagian besar guru masih belum terlalu tua sehingga kegiatan ceramah dan tutorialnya dapat dilakukan dengan tempo yang sedikit lebih cepat karena daya tangkapnya masih bisa dikatakan baik. Untuk membantu kegiatan pelatihan ini, pemateri dibantu oleh 4 orang Mahasiswa sebagai asisten dengan tujuan untuk mempercepat proses penyelesaian masalah yang terjadi saat kegiatan berlangsung.

\section{HASIL DAN PEMBAHASAN}

Kegiatan utama dalam pengabdian masyarakat ini berupa pelatihan mengoperasikan aplikasi video conference Zoom Meeting untuk mendukung aktivitas BDR dan strategi mengelola Google Form untuk evaluasi pembelajaran daring. Kegiatan dilaksanakan hari Rabu, 1 Juli 2020, bertempat di SD Muhammadiyah 16 Karangasem, Laweyan, Surakarta. Sesuai yang direncanakan, kegiatan dibagi menjadi dua sesi dengan jeda kurang lebih 15 menit untuk istirahat. Sesi pertama diisi dengan materi tentang cara mengoperasikan Zoom Meeting dan beberapa tips dalam menggunakannya untuk melaksanakan kegiatan pembelajaran daring.

$$
\text { Di bagian ini, guru peserta }
$$
memperoleh informasi terkait penggunaan aplikasi Zoom Meeting mulai dari tahap membuat akun, membuat jadwal pertemuan, membagikan link pertemuan hingga melakukan moderasi partisipan dan berbagi layar. Sementara, sesi kedua diisi dengan materi tentang cara memanfaatkan Google Form dan strateginya guna mendukung evaluasi pembelajaran daring, mulai dari membuat form sederhana beserta fungsi masing-masing form, membagikan link formulir, mengatur akses formulir, hingga mempraktikkan mengisi dan mengolah data pada formulir yang sudah dibuat.

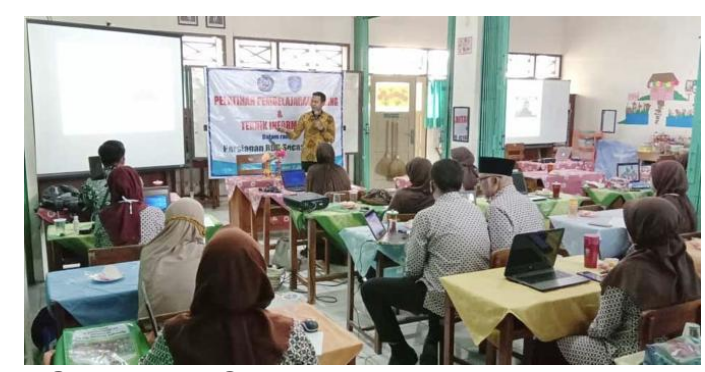

Gambar 5. Suasana penyampaian materi

Gambar 5 merupakan salah satu contoh suasana penyampaian materi yang diberikan secara singkat oleh narasumber dan peserta memperhatikan materi tersebut. Selama materi disampaikan, peserta juga diijinkan untuk bertanya setiap saat apabila terdapat sesuatu yang perlu diketahui. Selanjutnya, peserta diberikan kesempatan untuk mencoba dan mempraktikkan materi yang telah disampaikan agar suasana belajar menjadi aktif. Selain metode ceramah singkat, strategi yang digunakan adalah 
pembelajaran aktif atau active learning antara pemateri dan guru peserta. Strategi pembelajaran aktif ini memungkinkan pemberi dan penerima materi untuk saling berinteraksi dan lebih terikat dengan materi yang disampaikan (Torralba \& Doo, 2020). Sehingga dapat mendorong keduanya untuk berdiskusi secara langsung dan berpikir kritis tentang materi yang disampaikan.

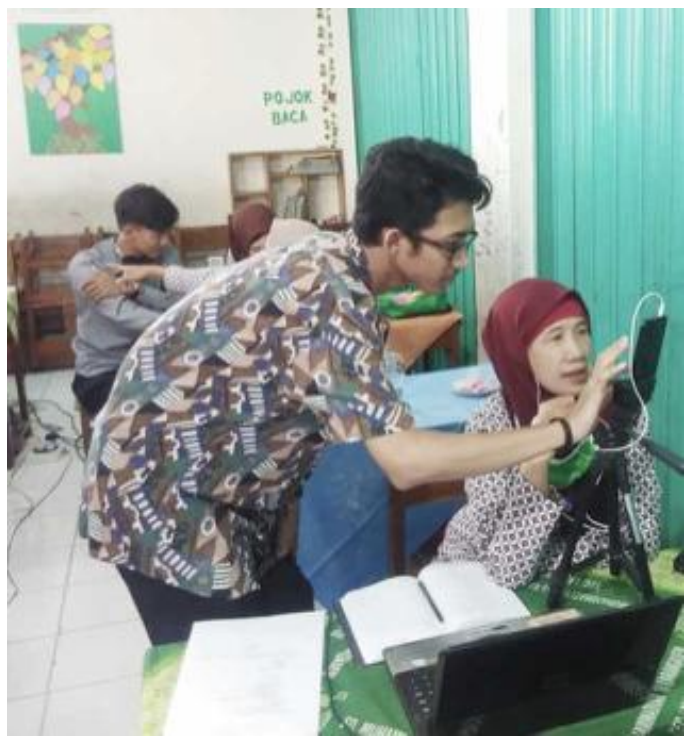

Gambar 6. Praktik langsung dan bimbingan teknis

Dalam pembelajaran aktif pada kegiatan ini, peserta memiliki kesempatan cukup banyak untuk bertanya secara lebih detil teknis-teknis mengenai aplikasi yang sedang dipelajari saat mengalami kesulitan. Seperti yang ditunjukkan pada Gambar 6 , seorang guru peserta menanyakan tentang cara membuat link pertemuan dan cara membagikan ke siswa agar bisa mengikuti belajar daring. Kemudian, salah satu asisten pemateri datang lebih mendekat untuk menanyakan kesulitan apa yang dialami dan menyampaikan solusi atas masalah yang dihadapi. Dilihat dari gambarnya, ternyata guru tersebut membawa tripod sendiri dari rumah lantaran benar-benar ingin belajar dan menguasai serta menerapkannya untuk aktivitas BDR. Sehingga, saat praktik menggunakan aplikasi menjadi lebih mudah mengikuti dan mengetahui secara jauh fitur yang terdapat di aplikasi Zoom Meeting saat aktivitas BDR berlangsung.

Kegiatan pelatihan berlangsung selama lebih dari 3 jam dan terlihat beberapa guru memang lancar dan tidak banyak yang mengalami kendala dalam mengikuti kegiatan pelatihan. Beberapa kesulitan yang dialami dianggap wajar dan dengan segera dapat ditangani dengan baik. Akan tetapi, terdapat satu peserta yang kesulitan saat akan membuat akun Zoom Meeting baru dan membuat jadwal pertemuan online. Berdasarkan informasi di web resmi aplikasi Zoom Meeting, penyebabnya yaitu server menganggap bahwa akun yang digunakan peserta tersebut sudah pernah didaftarkan sehingga tidak bisa dipakai lagi untuk mendaftar. Kesalahannya yaitu peserta tersebut lupa password akunnya dan berinisiatif untuk melakukan reset password. Akan tetapi, server Zoom meminta untuk menunggu beberapa jam agar bisa login menggunakan akun yang sama lantaran baru saja dilakukan reset.

Kondisi seperti itu tentu akan menyebabkan peserta tersebut ketinggalan materi yang disampaikan lantaran harus menunggu beberapa jam. Salah satu solusinya adalah peserta tersebut disarankan untuk 
menggunakan akun email lain yang masih aktif. Namun permasalahan lain muncul karena peserta itu hanya memiliki satu akun email saja yang berakibat harus membuat email baru dan membutuhkan waktu. Sebagai solusinya, maka peserta tersebut diberikan waktu membuat akun baru supaya dapat mendaftar Zoom Meeting dan membuat jadwal pertemuan serta mengoperasikan fitur yang terdapat di dalamnya. Agar tidak mengganggu peserta lain yang tidak mengalami kendala, asisten pemateri membantu masalah tersebut dengan baik sehingga dapat mengikuti dan melanjutkan sama seperti peserta lain.

Tabel 4. Hasil evaluasi kegiatan

\begin{tabular}{cl}
\hline Pertanyaan (P) & \multicolumn{1}{c}{ Persentase } \\
\hline P1 & $87,83 \%$ \\
P2 & $86,96 \%$ \\
P3 & $90,43 \%$ \\
P4 & $90,43 \%$ \\
P5 & $86,09 \%$ \\
P6 & $80 \%$ \\
\hline
\end{tabular}

Setelah selesai kegiatan pelatihan, peserta diminta untuk mengisi kuesioner yang pertanyaannya seperti disajikan pada tabel 3 . Kuesioner ini digunakan sebagai alat untuk mengukur sejauh mana respon atau tanggapan peserta terkait kegiatan yang telah dilaksanakan. Kuesioner dibagikan secara online melalui tautan yang dikirim lewat pesan singkat WhatsApp ke salah satu koordinator guru, kemudian diteruskan ke seluruh peserta melalui grup sekolah yang dimilikinya. Dari 24 peserta yang mengikuti kegiatan, sebanyak 23 orang mengisi kuesioner dan terdapat salah seorang peserta yang tidak ikut mengisi. Tidak diketahui penyebabnya karena pengisian kuesioner ini dilakukan secara sukarela tanpa ada paksaan, sehingga hasil kuesioner yang diperoleh memang benar-benar berasal dari apa yang dirasakannya. Nilai akumulasi hasil evaluasi melalui kuesioner untuk pertanyaan jenis tertutup (P1-P6) ditampilkan pada Tabel 4 yang disajikan dalam bentuk persentase kemudian diinterpretasikan sesuai dengan kategorinya.

Dari tabel 4 pertanyaan $\mathrm{P} 1$, diperoleh keterangan bahwa peserta menjadi lebih tahu cara mengoperasikan Zoom Meeting sebagai host untuk pembelajaran daring setelah mengikuti kegiatan pelatihan. Hal ini terlihat dari nilai ratarata jawaban kuesioner yang diisi peserta memiliki nilai sebesar $87,83 \%$, yang artinya bahwa mereka sangat setuju dengan pertanyaan $\mathrm{P} 1$. Dari nilai hasil jawaban pertanyaan P2 (86,96\%) juga dapat diperoleh keterangan bahwa peserta sangat setuju jika mereka mendapatkan informasi yang diinginkan untuk mendukung kegiatan BDR dari kegiatan pelatihan ini, sehingga dapat dikatakan bahwa mereka memperoleh pengetahuan seperti yang diharapkan.

Sementara itu, pertanyaan P3 dan P4 yang berkaitan dengan Google Form, akumulasi nilai rata-rata yang diperoleh adalah sama yaitu sebesar $90,43 \%$. Artinya, peserta juga sangat setuju jika mereka menjadi lebih tahu kegunaan dan manfaat Google Form untuk pembelajaran daring dari kegiatan pelatihan yang 
diselenggarakan ini. Lebih jauh dari itu, pertanyaan P4 terkait penggunaan Google Form, mereka menyatakan bahwa akan menggunakan Google Form sebagai salah satu strategi untuk evaluasi dalam pembelajaran daring setelah selesai dadi kegiatan pelatihan ini. Dengan demikian, bukan hanya informasi atau pengetahuan secara teori saja yang diperoleh, tetapi juga tindakan nyata untuk menerapkan ilmu yang telah didapatkan pasca kegiatan.

Dua pertanyaan tertutup terakhir, yaitu P5 dan P6 merupakan rangkuman jawaban atas beberapa pertanyaan sebelumnya (P1-P4) terkait semua aktivitas dalam pelatihan ini, mulai dari materi yang disampaikan hingga suasana pelatihan. Dari pertanyaan P5 diperoleh akumulasi jawaban yang nilai rata-ratanya sebesar $86,09 \%$, artinya bahwa mereka sangat setuju jika secara umum peserta merasa puas dengan kegiatan pelatihan ini. Selain itu, mereka juga menyatakan sangat setuju jika materi yang disampaikan dalam kegiatan ini sudah sesuai dengan yang diharapkan, yang ditunjukkan melalui akumulasi rata-rata jawaban atas pertanyaan P6 dengan nilai sebesar $80 \%$. Dengan demikian dapat dikatakan bahwa sasaran dari kegiatan pelatihan ini telah tercapai sesuai dengan tujuan, yaitu meningkatkan keterampilan mengoperasikan Zoom Meeting untuk aktivitas BDR dan kemampuan mengelola Google Form sebagai perangkat evaluasi di SD Muhammadiyah 16 Karangasem, Laweyan, Surakarta.

Pertanyaan terbuka P7 digunakan untuk menggali informasi terkait kegiatan sejenis yang berpotensi untuk dilaksanakan guna mendukung aktivitas BDR. Dari pertanyaan P7 terkait pelatihan sejenis apa saja yang diinginkan untuk mendukung BDR, diperoleh jawaban yang bervariasi antara lain menghendaki pelatihan membuat konten video pembelajaran, pengoperasian Google Meet, e-learning Schoology atau Google Classroom, media pembelajaran daring, dan pelatihan e-raport. Dari jawabanjawaban ini bisa diperoleh informasi bahwa ternyata banyak sekali keinginan para guru untuk meningkatkan keterampilan menggunakan perangkat teknologi guna mendukung aktivitas BDR yang lebih berkualitas sama seperti ketika belajar tatap muka secara langsung.

$\mathrm{Di}$ bagian akhir pertanyaan terbuka P8, peserta diberikan kesempatan untuk menyampaikan kritik dan saran terkait kegiatan pelatihan yang sudah diadakan. Tujuannya yaitu untuk perbaikan di masa yang akan datang saat mengadakan aktivitas sejenis. Beberapa kritik dan saran yang diberikan oleh peserta antara lain mengatakan bahwa asisten pendamping Mahasiswa perlu diperbanyak, waktu yang digunakan masih perlu ditambah, perlu agak pelan dalam penyampaian materi supaya yang berumur senja tidak ketinggalan, dan perlu sering untuk mengadakan kegiatan seperti ini agar keterampilan guru dalam menggunakan perangkat teknologi semakin mahir. Masukanmasukan ini akan digunakan sebagai pertimbangan apabila mengadakan kegiatan sejenis di masa yang akan datang. 


\section{KESIMPULAN}

Dari uraian pembahasan di atas dapat disimpulkan bahwa kegiatan ini memberikan kontribusi terhadap guru terkait keterampilan mengoperasikan Zoom Meeting dan mengelola Google Form untuk mendukung aktivitas BDR dan evaluasinya. Terlihat dari kuesioner yang dibagikan pertanyaan tertutup (P1-P6) diperoleh nilai akumulasi ratarata jawaban sama dengan atau di atas $80 \%$. Dari jawaban kuesioner yang diisikan peserta, secara umum mereka juga puas dengan materi yang disampaikan dan suasana kegiatan yang dilaksanakan. Selain itu, peserta juga menyatakan bahwa mereka merasa mendapatkan informasi dan pengetahuan sesuai dengan yang diharapkan untuk mendukung aktivitas BDR dan evaluasinya. Bahkan, mereka juga menginginkan pelatihan sejenis untuk meningkatkan kualitas BDR dan meningkatkan keterampilan dalam menggunakan perangkat teknologi pembelajaran daring. Meskipun begitu, peserta menganggap bahwa masih terdapat beberapa kekurangan yang perlu diperbaiki misalnya perlu menambah asisten pendamping dan menambah waktu kegiatan. Namun sangat disarankan untuk memastikan peserta agar selalu mengingat akun email dan kata sandinya saat mengikuti kegiatan seperti ini dan mungkin perlu diwajibkan sebagai syarat utama.

\section{DAFTAR PUSTAKA}

Dewi, W. A. F. (2020). Dampak Covid19 terhadap implementasi pembelajaran daring di Sekolah Dasar. Edukatif: Jurnal IImu Pendidikan, 2(1), 55-61.
Dvir, N., \& Schatz-Oppenheimer, O. (2020). Novice teachers in a changing reality. European Journal of Teacher Education, 43(4), 639656.

https://doi.org/10.1080/02619768. 2020.1821360

Haqien, D., \& Rahman, A. A. (2020). Pemanfaatan Zoom Meeting Untuk Proses Pembelajaran Pada Masa Pandemi Covid-19. SAP (Susunan Artikel Pendidikan), 5(1).

Magdalena, I., Hayati, K., Ningsih, M. W., \& Rosmiyanti, D. (2020). Teknik Pengolahan Hasil Evaluasi Belajar pada Mata Pelajaran Pendidikan Jasmani Olahraga dan Kesehatan di Kelas IV SDN Malangnengah II. Jurnal Halaqah, 2(4), 497-505.

Magdalena, I., Susanti, L. I., \& Rahmawati, S. (2020). Pengelolaan Evaluasi Pembelajaran Kurikulum 2013 di SDIT Gunung Jati. Jurnal Halaqah, 2(3), 294-298.

Mujahidin, E., Bahruddin, E., \& Hartono, R. (2020). The Role of Meeting Applications in Improving Student Productivity and Health Management amid Corona Virus Pandemic. Universal Journal of Educational Research, 8(9), 39653969.

https://doi.org/10.13189/ujer.2020. 080921

Mulyadi, E. (2020). Online Physics Learning Via Whatsapp, Google Form, And Email In The Achievement Of Active Presence And Student Learning Outcomes. Ideguru: Jurnal Karya IImiah Guru, 
Jurnal Widya Laksana, Vol.11, No.1, Januari 2022

5(1), 34-41.

Riduwan, M. B. A. (2007). Skala pengukuran variabel-variabel penelitian. Alf. Bandung.

Ritonga, M., Lahmi, A., Rimelfi, R., Bahri, F., \& Bagindo, I. T. (2020). Sosialisasi Pembuatan Soal Melalui Google Form Dalam Meningkatkan Kompetensi Guru Pai. BERNAS: Jurnal Pengabdian Kepada Masyarakat, 1(4), 347354.

Rohman, A., \& Rochmawati, N. I. (2020). Pemanfaatan Aplikasi Zoom dan Google Meet Untuk Pembelajaran Daring di TK Pembina ABA 54 dan KB 'Aisyiyah 18 Semarang. Multimatrix, 2(2).

Sari, W., Rifki, A. M., \& Karmila, M. (2020). ANALISIS KEBIJAKAN
PENDIDIKAN

IMPLEMENTASI

PEMBELAJARAN JARAK JAUH

PADA MASA DARURAT COVID 19. JURNAL MAPPESONA, 2(2).

Sukirman, S., Putra, M., \& Kusumawati, A. (2019). Optimalisasi Penggunaan Aplikasi Cloud Computing Sebagai Sarana Pengelolaan Kuesioner Bagi Guru Muhammadiyah Tanon. Warta LPM, 22(2), 120-128. https://doi.org/10.23917/warta.v22i 2.8664

Torralba, K. D., \& Doo, L. (2020). Active Learning Strategies to Improve Progression from Knowledge to Action. Rheumatic Disease Clinics of North America, 46(1), 1-19. https://doi.org/https://doi.org/10.10 16/j.rdc.2019.09.001 